\title{
EFFICACY OF SINGLE-DOSE OF DEXAMETHASONE IN REDUCTION OF PAIN, NAUSEA AND VOMITING AFTER LAPAROSCOPIC CHOLECYSTECTOMY- A RANDOMISED CONTROLLED TRIAL
}

\author{
Hossein Emami1, Novin Nikbakhsh², Bahman Hassan Nassab3 ${ }^{3}$,Soraya Khafri ${ }^{4}$, Ali Asghar Darzi ${ }^{5}$
}

1MD, Student Research Committee, School of Medicine, Babol University of Medical Sciences, Babol, Iran.

${ }^{2}$ Associate Professor, Department of Surgery, Cancer Research Center, Health Research Institute, Babol University of Medical Sciences, Babol, Iran.

${ }_{3}^{3}$ Assistant Professor, Department of Anaesthesia, Babol University of Medical Sciences, Babol, Iran.

${ }^{4}$ Assistant Professor, Department of Biostatistics and Epidemiology, Medicine Faculty, Babol University of Medical Sciences, Babol, Iran. ${ }^{5}$ Associate Professor, Department of Surgery, Clinical Research Development Center, Shahid Beheshti Hospital, Babol University of Medical Sciences, Babol, Iran.

\begin{tabular}{l}
\hline ABSTRACT \\
BACKGROUND \\
Dexamethasone is an available and cheap drug and has low complications. There are not enough studies on antiemetic and \\
analgesic effects of dexamethasone after laparoscopic cholecystectomy. \\
The aim of this study was to assess the efficacy of single-dose of dexamethasone on Postoperative Pain (POP) and Nausea and \\
Vomiting (PONV) in the patients undergoing laparoscopic cholecystectomy in northern Iran.
\end{tabular}

\section{MATERIALS AND METHODS}

This randomised controlled trial was conducted on 140 patients who were candidates for laparoscopic cholecystectomy. The subjects were randomly assigned into Group I (dexamethasone $8 \mathrm{mg}$ ) and Group II (normal saline $5 \mathrm{~mL}$ ). Each group had 70 patients. The subjects were followed about POP and PONV every 4 hours for 12 hours after the operation using Nausea and Vomiting Scale (NVS) and Visual Analogue Scale (VAS) pain scores.

\section{RESULTS}

Seven patients $(12.1 \%)$ were men and $123(87.9 \%)$ were women. The mean age was $44.37 \pm 8.69$ years old. The mean NVS score was significantly different between the two groups in both periods $0-4$ hours (Group I: $1.06 \pm 0.85$, Group II: $1.38 \pm 1.00$; p= 0.043 ) and 4 - 8 (Group I: $0.58 \pm 0.24$, Group II: $0.67 \pm 0.29$; p= 0.047) hours after the surgery. About VAS pain score, there were significant mean differences between the two groups in both periods $4-8$ hours (Group I: $4.09 \pm 1.01$, Group II: 4.49 \pm 1.24 ; p= 0.038 ) and 8 - 12 hours (Group I: $2.06 \pm 0.81$, Group II: $2.47 \pm 1.16$; $p=0.017$ ) after the surgery.

\section{CONCLUSION}

According to the findings, single-dose of dexamethasone had a significant reducing effect on POP and PONV in the patients undergoing laparoscopic cholecystectomy.

\section{KEY WORDS}

Dexamethasone, Pain, Nausea, Vomiting, Cholecystectomy.

HOW TO CITE THIS ARTICLE: Emami H, Nikbakhsh N, Nassab BH, et al. Efficacy of single-dose of dexamethasone in reduction of pain, nausea and vomiting after laparoscopic cholecystectomy- a randomised controlled trial. J. Evolution Med. Dent. Sci. 2018;7(35):3825-3829, DOI: 10.14260/jemds/2018/858

\section{BACKGROUND}

Gallstone is one of the common gastrointestinal diseases. Presently, the gold-standard for treatment of gallstones is laparoscopic cholecystectomy.(1) Despite the advantages of laparoscopic cholecystectomy versus open cholecystectomy, Postoperative Pain (POP) Nausea and Vomiting (PONV) are very irritating.(2)

POP is one of the specific complications of elective laparoscopic cholecystectomy that frequently occurs immediately after the surgery.(3-5) Finding a way to better control and decrease POP has always been a question for

'Financial or Other Competing Interest': None.

Submission 19-07-2018, Peer Review 13-08-2018,

Acceptance 19-08-2018, Published 27-08-2018.

Corresponding Author:

Dr. Ali Asghar Darzi,

Department of Surgery,

Babol University of Medical Sciences,

Ganjafrooz Street, Babol, Mazandaran, Iran.

E-mail: alidarzi@yahoo.com

DOI: $10.14260 /$ jemds $/ 2018 / 858$

\section{(c) (i) $\$$}

surgeons considering that pain has an important role in hospitalisation duration, rate of patient's satisfaction, duration of recovery and getting back to activities of daily living.(6,7) The usual method for controlling the postoperative pains is with the use of opioids. These agents can lead to important complications, such as respiratory failure. Also, they can be associated with substance abuse.(8,9) Therefore, their replacement by less dangerous drugs has always been discussed.

Postoperative Nausea and Vomiting (PONV) is one of the bothersome problems after surgeries with general anaesthesia. PONV is defined in the first 24 hours after surgery and can be seen in up to $80 \%$ of high risk patients.(10-12) PONV can be so unpleasant that most of the patients prefer to experience POP instead. PONV can lead to dehydration, electrolyte imbalance, hypoxia, increase in blood pressure, stretch stitches, increase in duration of hospitalisation, delay in discharge, health care costs and secondary complications such as atelectasis, ileus and deep venous thrombosis.(13-15) According to the reports, prevalence of PONV is between $20 \%$ and $30 \%$ among adult patients.(16) 
Additionally, its prevalence varies up to $75 \%$ in laparoscopic cholecystectomy.(17) Selection of the preventive method against PONV should be based on safety, efficacy, patient's satisfaction and cost-benefit. Antagonists of dopamine, chlorpromazine and metoclopramide, anticholinergic, antihistamines and dimenhydrinate have been used in this regard, but they have their own advantages and disadvantages.(18,19)

There are not enough evidence on the efficacy of dexamethasone on PONV and POP in laparoscopic cholecystectomy. Given that dexamethasone is an available and cheap drug and have low complications, and also considering that there was not any related surveys in our region, we aimed to conduct a study to evaluate the effectiveness of dexamethasone on PONV and POP in patients undergoing laparoscopic cholecystectomy in north of Iran.

\section{MATERIALS AND METHODS}

\section{Locations and Participants}

This single-blind randomised controlled trial was performed on patients who underwent the elective laparoscopic cholecystectomy in Shahid Beheshti, Babol Clinic and Ayatollah Rouhani Hospitals in Babol, Northern Iran, during 2015.

Inclusion criteria were the patients who underwent laparoscopic cholecystectomy and aged 20 - 70 years old. The exclusion criteria were as follows: 1) Patients with digestive diseases potentially increase the risk of PONV, such as gastrooesophageal reflux disease; 2) Diabetic patients; 3) Smokers; 4) Patients with jaundice; 4) Patients with history of PONV.

\section{Randomisation and Surgery}

Subjects were randomly allocated into two groups using a computer-generated random number table: 1) Patients who received $8 \mathrm{mg}$ dexamethasone intravenously after the surgery and before the extubation; 2) Patients who received $5 \mathrm{~mL}$ normal saline intravenously after the surgery [placebo group]. The patients were blinded to the treatment assignment.

General anaesthesia was induced with propofol $2 \mathrm{mg}$ and fentanyl $2 \mu \mathrm{g}$ under the supervision of an anaesthetist. Electrocardiogram, blood pressure, pulse oximetry and capnometry were monitored during the anaesthesia period. All subjects underwent laparoscopic cholecystectomy by the same surgeon. The abdomen was insufflated with $\mathrm{CO} 2$ and the patient was put in a reverse Trendelenburg position. To control POP and PONV, pethidine $30 \mathrm{mg}$ every 4 hours and metoclopramide $20 \mathrm{mg}$ every 4 hours were administered if needed, respectively.

\section{Sample Size Calculation}

The sample size of 70 patients in each group was estimated by a non-inferiority margin of $\delta=-0.1$ that was based on clinical judgement with $80 \%$ power and type I error rate of $5 \%$. In addition, the proportion of the study outcome (=number of patients experiencing nausea in the first 4 hours of surgery) in dexamethasone and placebo groups was considered as $30 \%$ and $60 \%$.

\section{Data Collection}

All necessary data were gathered by a checklist containing demographic information (Age, sex, body mass index) and other variables including hospitalisation duration, disease type (Acute cholecystitis, chronic cholecystitis, biliary colic), duration of surgery and postoperative complications (Pain, nausea and vomiting).

The patients were followed up in terms of incidence of pain, nausea and vomiting every 4 hours for 12 hours after the surgery. To assess the nausea and vomiting, we used Nausea and Vomiting Scale (NVS) as well. The severity of nausea/ vomiting was graded into 4 categories, scoring ranged from 0 (Without nausea) to 4 (Severe vomiting [continuous]).(17) In order to evaluate the severity of pain, Visual Analogue Scale (VAS) was used. VAS score ranges from 0 (no pain) to 10 (worst possible pain).(20) The patients were explained about these scores in the pre-operative visit.

\section{Statistical Analysis}

The collected data were analysed by SPSS using descriptive, chi-square and t-test statistics. We compared the type of disease (Acute/ Chronic Cholecystitis, Biliary Colic), sex, age, body mass index, hospitalisation duration, surgery duration between the two groups. We also compared the mean scores of VAS and NVS between the two groups by different time periods. P-value less than 0.05 was considered to be statistically significant.

\section{Ethical Issues}

The informed consent was taken from all subjects. The patients' information was kept confidential. This study was approved by the Ethical Research Committee of Babol University of Medical Sciences (Code Number: MUBABOL.REC.1394.229).

\section{RESULTS}

In this study, 140 patients were finally recruited, of whom 17 $(12.1 \%)$ were men and $123(87.9 \%)$ were women with mean age of $44.37 \pm 8.69$ years old. Groups I (dexamethasone) and II (normal saline) had an equal number of subjects $(n=70)$. The CONSORT flow-diagram of the participants is exhibited in Figure 1. The characteristics of the patients were indicated in Table 1 as well. There were not any significant differences between the two groups in terms of the variables.

Comparison of the mean NVS scores between the two groups in different time periods is shown in Table 2. The mean score in group of dexamethasone was significantly more than in group of normal saline in both periods $0-4$ hours and 4 - 8 hours after the surgery, but the mean difference was not significant in period $8-12$ hours between the two groups.

In the first 4 hours after the surgery, 39 subjects (55.7\%) in Group II experienced nausea, while this rate was 27 (38.6\%) in Group I ( $\mathrm{p}=0.042)$. The number of patients who had nausea in period $4-8$ hours after the surgery was 26 (37.1\%) in Group II and 15 (21.4\%) in Group I ( $p=0.041)$ Besides, in the first 4 hours period, there was a significant difference between Group I $(n=18,25.7 \%)$ and Group II $(n=29,41.4 \%)$ in the occurrence of postoperative vomiting (Table 3).

Regarding VAS pain score, there were significant mean differences between the two groups in both periods $4-8$ hours (Group I: $4.09 \pm 1.01$, Group II: $4.49 \pm 1.24$; p= 0.038) and 8 - 12 hours (Group I: $2.06 \pm 0.81$, Group II: $2.47 \pm 1.16$; $\mathrm{p}=0.017$ ) after the surgery, although we did not find a significant mean difference in the first 4 hours (Table 4). 


\begin{tabular}{|c|c|c|c|}
\hline Variables & $\begin{array}{c}\text { Group I } \\
\text { (Dexamethasone } \\
n=70)\end{array}$ & $\begin{array}{c}\text { Group II } \\
\text { (Normal } \\
\text { Saline, } n=70)\end{array}$ & $\begin{array}{c}\text { P- } \\
\text { value }\end{array}$ \\
\hline \multicolumn{4}{|l|}{ Sex, n (\%) } \\
\hline Men & $9(12.9)$ & $8(11.4)$ & \multirow{2}{*}{0.796} \\
\hline Women & $61(87.1)$ & $62(88.6)$ & \\
\hline \multicolumn{4}{|l|}{$\begin{array}{c}\text { Age Group } \\
\text { (Years), n (\%) }\end{array}$} \\
\hline$\leq 40$ & $32(45.7)$ & $25(35.7)$ & \multirow{2}{*}{0.229} \\
\hline$>40$ & $38(54.3)$ & $45(64.3)$ & \\
\hline $\begin{array}{l}\text { Age (Years), } \\
\text { Mean } \pm \text { SD }\end{array}$ & $43.39 \pm 11.69$ & $45.24 \pm 11.66$ & 0.350 \\
\hline \multicolumn{4}{|l|}{$\begin{array}{c}\text { Body Mass Index } \\
\text { (BMI), n (\%) }\end{array}$} \\
\hline $\begin{array}{c}\text { Normal (BMI: 18.5- } \\
24.9)\end{array}$ & $35(50)$ & $29(41.4)$ & \multirow{3}{*}{0.413} \\
\hline $\begin{array}{c}\text { Overweight (BMI: } \\
25-29.9 \text { ) }\end{array}$ & $30(42.9)$ & 32 (45.7) & \\
\hline Obesity (BMI: $\geq 30$ ) & $5(7.1)$ & $9(12.9)$ & \\
\hline \multicolumn{4}{|l|}{$\begin{array}{c}\text { Disease Type, } \\
\text { n (\%) } \\
\end{array}$} \\
\hline Acute cholecystitis & $6(8.6)$ & $9(12.9)$ & \multirow{3}{*}{0.526} \\
\hline $\begin{array}{c}\text { Chronic } \\
\text { cholecystitis }\end{array}$ & $51(72.8)$ & $45(64.2)$ & \\
\hline Biliary colic & $13(18.6)$ & $16(22.9)$ & \\
\hline $\begin{array}{l}\text { Duration of surgery } \\
\text { (minute), Mean } \pm \text { SD }\end{array}$ & $28.94 \pm 5.95$ & $31.50 \pm 11.1$ & 0.091 \\
\hline $\begin{array}{c}\text { Duration of } \\
\text { hospitalisation } \\
\text { (hour), Mean } \pm \text { SD }\end{array}$ & $24.00 \pm 1.33$ & $26.10 \pm 8.89$ & 0.053 \\
\hline Table 1. C & Characteristics & e Subjects & \\
\hline
\end{tabular}

\begin{tabular}{|c|c|c|c|}
\hline \multirow{2}{*}{$\begin{array}{c}\text { Time } \\
\text { (Hour) }\end{array}$} & $\begin{array}{c}\text { Nausea and Vomiting Scale (Mean } \pm \text { SD) } \\
\text { (Dexamethasone, } \\
\mathbf{n = 7 0 )}\end{array}$ & $\begin{array}{c}\text { Group II } \\
\text { (Normal Saline, } \\
\mathbf{n = 7 0 )}\end{array}$ & P-value \\
\hline $0-4$ & $1.06 \pm 0.85$ & $1.38 \pm 1.00$ & 0.043 \\
\hline $4-8$ & $0.58 \pm 0.24$ & $0.67 \pm 0.29$ & 0.047 \\
\hline $8-12$ & $0.10 \pm 0.07$ & $0.11 \pm 0.06$ & 0.366 \\
\hline \multicolumn{2}{|c|}{ Table 2. Comparison of Postoperative Nausea and } \\
\hline
\end{tabular}
Vomiting Scale between the Two Groups

\begin{tabular}{|c|c|c|c|}
\hline $\begin{array}{c}\text { Nausea/ } \\
\text { Vomiting }\end{array}$ & $\begin{array}{c}\text { Group I } \\
\text { (Dexamethasone, } \\
\mathbf{n = 7 0 )}\end{array}$ & $\begin{array}{c}\text { Group II } \\
\text { (Normal } \\
\text { Saline, n=70) }\end{array}$ & $\begin{array}{c}\text { P- } \\
\text { value }\end{array}$ \\
\hline Nausea (n, \%) & & & \\
\hline $0-4 \mathrm{~h}$ & $27(38.6)$ & $39(55.7)$ & 0.042 \\
\hline $4-8 \mathrm{~h}$ & $15(21.4)$ & $26(37.1)$ & 0.041 \\
\hline $8-12 \mathrm{~h}$ & $4(5.7)$ & $7(10)$ & 0.346 \\
\hline Vomiting (n, \%) & & & \\
\hline $0-4 \mathrm{~h}$ & $18(25.7)$ & $29(41.4)$ & 0.049 \\
\hline $4-8 \mathrm{~h}$ & $8(11.4)$ & $10(14.3)$ & 0.613 \\
\hline $8-12 \mathrm{~h}$ & $2(2.9)$ & $3(4.3)$ & 0.649 \\
\hline
\end{tabular}

Table 3. Number of patients experiencing Postoperative Nausea or Vomiting

\begin{tabular}{|c|c|c|c|}
\hline \multirow[b]{2}{*}{$\begin{array}{c}\text { Time } \\
\text { (Hour) }\end{array}$} & \multicolumn{2}{|c|}{ Visual Analogue Scale (Mean \pm SD) } & \multirow[b]{2}{*}{ P-value } \\
\hline & $\begin{array}{c}\text { Group I } \\
\text { (Dexamethasone, } \\
\mathbf{n = 7 0 )}\end{array}$ & $\begin{array}{l}\text { Group II (Normal } \\
\text { Saline, } n=70 \text { ) }\end{array}$ & \\
\hline $0-4$ & $6.17 \pm 1.00$ & $6.46 \pm 1.28$ & 0.138 \\
\hline $4-8$ & $4.09 \pm 1.01$ & $4.49 \pm 1.24$ & 0.038 \\
\hline 8-12 & $2.06 \pm 0.81$ & $2.47 \pm 1.16$ & 0.017 \\
\hline
\end{tabular}

Table 4. Comparison of postoperative Visual Analogue Scale pain score between the Two Groups

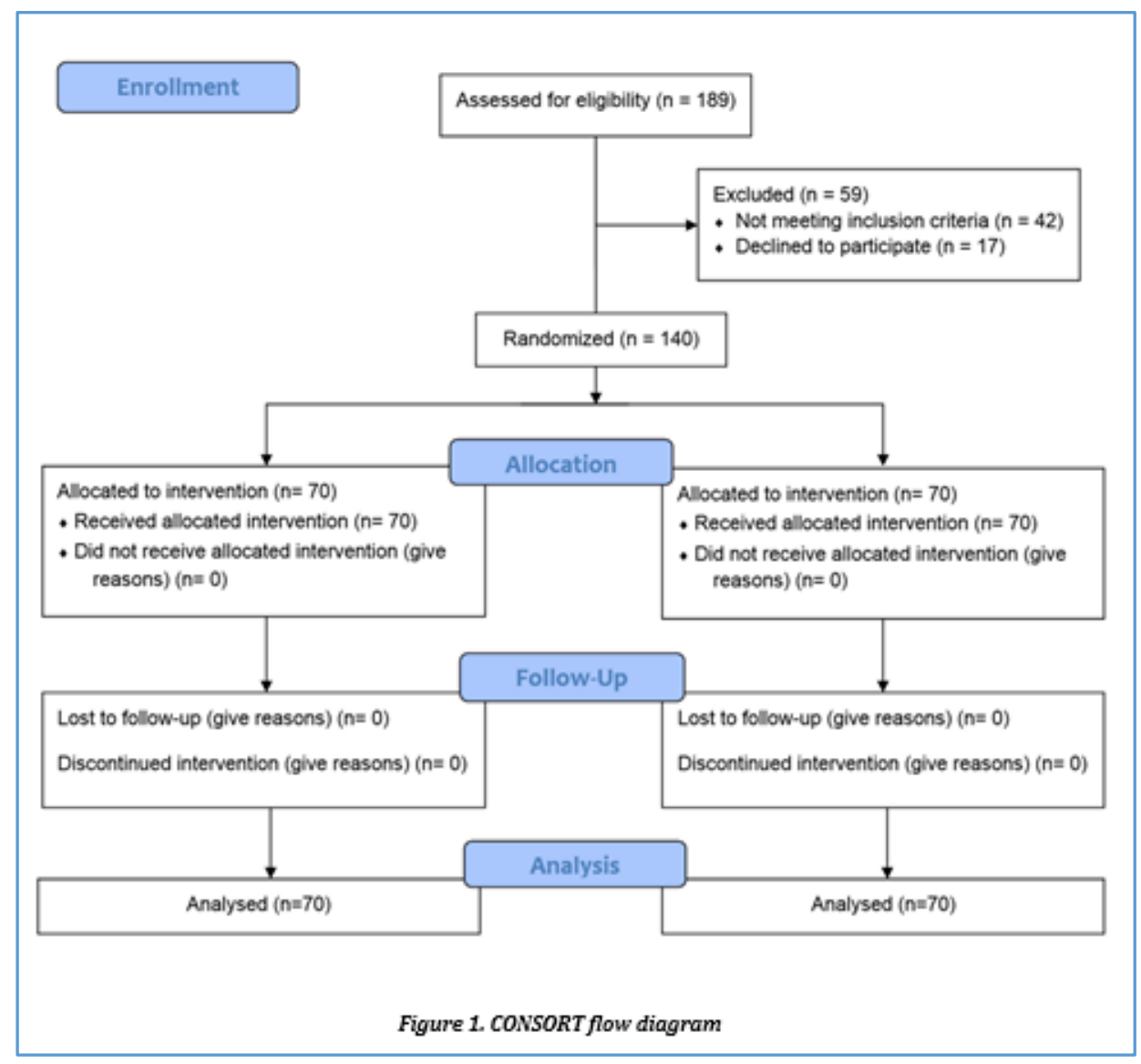




\section{DISCUSSION}

Our results showed that the mean score of NVS significantly decreased in patients who received dexamethasone compared with the normal saline group by the first 8 hours after the laparoscopic cholecystectomy. Of course in the period of 8 - 12 hours after the surgery, the mean difference between the two groups was not significant in NVS and therefore we can say that dexamethasone was not effective on nausea and vomiting since 8 hours after the surgery and was only effective in the first postoperative hours. Different reports are available on the preventive effect of dexamethasone on PONV.(21,22) Similar to our findings, Wang et $\mathrm{al}^{(23)}$ indicated that administration of dexamethasone decreases the incidence of PONV in patients who underwent laparoscopic cholecystectomy. In the study by Alkaissi et $\mathrm{al},(24)$ it was found that dexamethasone is more effective than metoclopramide in preventing PONV. The meta-analysis by $\mathrm{Si}$ et $\mathrm{al}^{(25)}$ revealed that the combination of dexamethasone plus other antiemetic agents is more effective than the single antiemetics for preventing PONV after laparoscopic cholecystectomy. Also, the study by Arslan et al(17) showed that combined propofol with dexamethasone is more effective in preventing PONV than combination of propofol plus metoclopramide. Although, metoclopramide is the most commonly used drug to prevent PONV, the previously published data have been in favour of dexamethasone in this regard. Lopez-Olaondo et al reported that there is no difference between dexamethasone and ondansetron in terms of antiemetic effect.(26) Ondansetron is another drug that is used for these events, but is more expensive than dexamethasone, so considering the similarity in the efficacy dexamethasone is more suitable.

The exact mechanism by which dexamethasone act as an antiemetic is still unclear. However, some hypotheses have been raised: A) Anti-inflammatory effect by inhibition of production of prostaglandins; B) Inhibition of synthesis or secretion of serotonin; C) Interaction with alpha-adrenaline, tachykinin NK1 and NK2 receptors; D) Regulation of the hypothalamic-pituitary-adrenal axis.(25,27)

One of the other complications after the laparoscopic cholecystectomy is pain, which can vary from a mild pain in the surgical site to severe abdominal pain radiating to the back.(28-30) In our study, dexamethasone could significantly have a reducing effect on POP in the patients. SánchezRodríguez et al(31) also found that intravenous single-dose of $8 \mathrm{mg}$ dexamethasone significantly decreased POP until 24 hours after the laparoscopic cholecystectomy with the difference that we witnessed analgesic effect since 4 hours after the surgery. As well, Mohtadi et al(32) showed similar results to ours until 12 hours of the surgery. On the other hand, contrary findings have been reported.(33,34) Different causes can lead to the pain after the laparoscopic cholecystectomy directly and indirectly such as skin incision, diaphragmatic irritation, underlying disease and surgical factors. The analgesic mechanism of dexamethasone has not been precisely determined, but some possibilities exist: A) Inhibition of peripheral phospholipase enzyme, leading to reduction of cyclooxygenase and lipoxygenase synthesis in the inflammatory response; B) Decrease in bradykinin (an inflammatory mediator), which is involved in pain processing in the operated area; C) Reduction of the neuropeptides participating in sensory nerve reactions to injuries.(35-37)

\section{Limitations}

One of the study limitations was a short duration of followup, only until 12 hours after the surgery. We also suggest that more studies be done on different doses of dexamethasone with measurement of serum concentration of the drug.

\section{CONCLUSION}

According to the findings, single-dose of dexamethasone significantly reduced POP and PONV of the patients underwent laparoscopic cholecystectomy. Considering the mentioned results, and also given that dexamethasone is a cheap and accessible drug it is recommended to use it as an antiemetic agent in such surgeries.

\section{ACKNOWLEDGEMENT}

We would like to thank the Vice Chancellor for Research of Babol University of Medical Sciences for supporting our study.

\section{REFERENCES}

[1] Pan MX, Jiang ZS, Cheng Y, et al. Single-incision vs three-port laparoscopic cholecystectomy: prospective randomized study. World J Gastroenterol 2013;19(3):394-8.

[2] Coccolini F, Catena F, Pisano M, et al. Open versus laparoscopic cholecystectomy in acute cholecystectomy. Systematic review and metaanalysis. Int J Surg 2015;18:196-204.

[3] Szental J, Webb A, Weeraratne C, et al. Postoperative pain after laparoscopic cholecystectomy is not reduced by intraoperative analgesia guided by analgesia nociception index (ANI®) monitoring: a randomized clinical trial. $\mathrm{Br} J$ Anaesth 2015;114(4):640-5.

[4] Luo J, Min S. Postoperative pain management in the post-anesthesia care unit: an update. J Pain Res 2017; 10:2687-98.

[5] Das NT, Deshpande C. Effects of intraperitoneal local anaesthetics bupivacaine and ropivacaine versus placebo on postoperative pain after laparoscopic cholecystectomy: a randomised double blind study. J Clin Diagn Res 2017;11(7):UC08-UC12.

[6] Lau H, Brooks DC. Predictive factors for unanticipated admissions after ambulatory laparoscopic cholecystectomy. Arch Surg 2001;136(10):1150-3.

[7] Blondal K, Halldorsdottir S. The challenge of caring for patients in pain: from the nurse's perspective. J Clin Nurs 2009;18(20):2897-906.

[8] Wheeler M, Oderda GM, Ashburn MA, et al. Adverse events associated with postoperative opioid analgesia: a systematic review. J Pain 2002;3(3):159-80.

[9] Oderda GM, Gan TJ, Johnson BH, et al. Effect of opioidrelated adverse events on outcomes in selected surgical patients. J Pain Palliat Care Pharmacother 2013;27(1):62-70.

[10] Orhan-Sungur M, Kranke P, Sessler D, et al. Does supplemental oxygen reduce postoperative nausea and vomiting? A meta-analysis of randomized controlled trials. Anesth Analg 2008;106(6):1733-8. 
[11] Khatiwada S, Bhattarai B, Biswas BK, et al. Postoperative nausea and vomiting in patients undergoing total abdominal hysterectomy under subarachnoid block: a randomized study of dexamethasone prophylaxis. Kathmandu Univ Med J (KUMJ) 2012;10(38):41-5.

[12] Apipan B, Rummasak D, Wongsirichat N Postoperative nausea and vomiting after general anesthesia for oral and maxillofacial surgery. J Dent Anesth Pain Med 2016;16(4):273-81.

[13] Chohedri A, Matin M, Khosravi A. The impact of operative fluids on the prevention of postoperative anesthetic complications in ambulatory surgery--high dose Vs low dose. Middle East J Anaesthesiol 2006;18(6):1147-56.

[14] Wiesmann T, Kranke P, Eberhart L. Postoperative nausea and vomiting - a narrative review of pathophysiology, pharmacotherapy and clinical management strategies. Expert Opin Pharmacother 2015;16(7):1069-77.

[15] Thompson HJ. The management of post-operative nausea and vomiting. J Adv Nurs 1999;29(5):1130-6.

[16] McCracken G, Houston P, Lefebvre G, et al. Guideline for the management of postoperative nausea and vomiting. Journal of Obstetrics and Gynaecology Canada 2008;30(7):600-7, 608-16.

[17] Arslan M, Çiçek R, Kalender HÜ, et al. Preventing postoperative nausea and vomiting after laparoscopic cholecystectomy: a prospective, randomized, doubleblind study. Curr Ther Res Clin Exp 2011;72(1):1-12.

[18] Weibel S, Jelting Y, Pace NL, et al. Drugs for preventing postoperative nausea and vomiting in adults after general anaesthesia: a network meta-analysis. Cochrane Database Syst Rev 2017.

[19] Gan TJ, Diemunsch P, Habib AS, et al. Consensus guidelines for the management of postoperative nausea and vomiting. Anesth Analg 2014;118(1):85113.

[20] Williamson A, Hoggart B. Pain: a review of three commonly used pain rating scales. J Clin Nurs 2005;14(7):798-804.

[21] Habib AS, Gan TJ. Evidence-based management of postoperative nausea and vomiting: a review. Can J Anaesth 2004;51(4):326-41.

[22] Rüsch D, Eberhart L, Biedler A, et al. Prospective application of a simplified risk score to prevent postoperative nausea and vomiting. Can J Anaesth 2005;52(5):478-84.

[23] Wang J, Ho ST, Liu YH, et al. Dexamethasone reduces nausea and vomiting after laparoscopic cholecystectomy. Br J Anaesth 1999;83(5):772-5.

[24] Alkaissi A, Dwaikat M, Almasri N. Dexamethasone, metoclopramide, and their combination for the prevention of postoperative nausea and vomiting in female patients with moderate-to-high risk for ponv undergoing laparoscopic surgery. J Evolution Med Dent Sci 2017;6(75):5353-9.
[25] Si XY, Wu LP, Li XD, et al. Dexamethasone combined with other antiemetics for prophylaxis after laparoscopic cholecystectomy. Asian J Surg 2015;38(1):21-7.

[26] Lopez-Olaondo L, Carrascosa F, Pueyo FJ, et al. Combination of ondansetron and dexamethasone in the prophylaxis of postoperative nausea and vomiting. Br J Anaesth 1996;76(6):835-40.

[27] Chu CC, Hsing $\mathrm{CH}$, Shieh JP, et al. The cellular mechanisms of the antiemetic action of dexamethasone and related glucocorticoids against vomiting. Eur J Pharmacol 2014;722:48-54.

[28] Chang SKY, Wang YL, Shen L, et al. A randomized controlled trial comparing post-operative pain in single-incision laparoscopic cholecystectomy versus conventional laparoscopic cholecystectomy. World J Surg 2015;39(4):897-904.

[29] Singla S, Mittal G, Raghav, et al. Pain management after laparoscopic cholecystectomy-a randomized prospective trial of low pressure and standard pressure pneumoperitoneum. J Clin Diagn Res 2014;8(2):92-4.

[30] Gupta M, Naithani U, Singariya G, et al. Comparison of $0.25 \%$ ropivacaine for intraperitoneal instillation $\mathrm{v} / \mathrm{s}$ rectus sheath block for postoperative pain relief following laparoscopic cholecystectomy: a prospective study. J Clin Diagn Res 2016;10(8):UC10-UC15.

[31] Sánchez-Rodríguez PE, Fuentes-Orozco C, GonzálezOjeda A. Effect of dexamethasone on postoperative symptoms in patients undergoing elective laparoscopic cholecystectomy: randomized clinical trial. World J Surg 2010;34(5):895-900.

[32] Mohtadi A, Nesioonpour S, Salari A, et al. The effect of single-dose administration of dexamethasone on postoperative pain in patients undergoing laparoscopic cholecystectomy. Anesth Pain Med 2014;4(3):e17872.

[33] Elhakim M, Nafie M, Mahmoud K, et al. Dexamethasone $8 \mathrm{mg}$ in combination with ondansetron $4 \mathrm{mg}$ appears to be the optimal dose for the prevention of nausea and vomiting after laparoscopic cholecystectomy. Can J Anaesth 2002;49(9):922-6.

[34] Feo C, Sortini D, Ragazzi R, et al. Randomized clinical trial of the effect of preoperative dexamethasone on nausea and vomiting after laparoscopic cholecystectomy. Br J Surg 2006;93(3):295-9.

[35] Lim SH, Jang EH, Kim MH, et al. Analgesic effect of preoperative versus intraoperative dexamethasone after laparoscopic cholecystectomy with multimodal analgesia. Korean J Anesthesiol 2011;61(4):315-9.

[36] Hargreaves KM, Costello A. Glucocorticoids suppress levels of immunoreactive bradykinin in inflamed tissue as evaluated by micro dialysis probes. Clin Pharmacol Ther 1990;48(2):168-78.

[37] Hong D, Byers MR, Oswald RJ. Dexamethasone treatment reduces sensory neuropeptides and nerve sprouting reactions in injured teeth. Pain 1993;55(2):171-81. 